\section{Nauplius}

The Journal OF The

Brazilian Crustacean Society

e-ISSN 2358-2936

www.scielo.br/nau www.crustacea.org.br

\title{
Occurrence and distribution of early juvenile land hermit crabs at a small beach on the Boso Peninsula, Japan
}

\author{
Soshi Inutsuka ${ }^{\top}$
}

Katsuyuki Hamasaki ${ }^{1}$ orcid.org/0000-0002-2978-8490

Shigeki Dan'10 orcid.org/0000-0003-4057-6816

Shuichi Kitada' (1) orcid.org/0000-0001-5838-0374 1 Department of Marine Biosciences, Tokyo University of Marine Science and
Technology. 4-5-7 Konan, Minato, Tokyo 108-8477, Japan.
SI E-mail: oguchiboya@yahoo.co.jp
KH E-mail: hamak@kaiyodai.ac.jp
SD E-mail: sdan@kaiyodai.ac.jp
SK E-mail: kitada@kaiyodai.ac.jp
zOOBANK: http://zoobank.org/urn:lsid:zoobank.org:pub:0882A709-0102-47B6-
8EB7-55074FF49107

\section{ABSTRACt}

The present study was conducted to examine the occurrence and distribution of early juvenile land hermit crabs of the genus Coenobita on a small beach on the Boso Peninsula, Japan as a basis for understanding the important habitats that land hermit crabs use during the sea-to-land transition. The survey sites were supratidal zones at six points with heterogeneous topography, and visual surveys for early juveniles were conducted from middle July to late October in 2015 and 2016. The number of empty gastropod shells in four quadrats along the intertidal zone at each point was also counted in the 2016 survey. The occurrence of early juveniles varied among survey points and was spatially stable for two successive years. The first appearance and abundance of early juveniles varied among survey years. Early juveniles were abundant at points with a gravel bottom throughout the intertidal zone, and empty gastropod shells were also abundant at these points. The abundance of early juveniles was highly correlated with the amount of empty gastropod shells. Thus, our surveys suggested the importance of the sediment types and abundance of empty gastropod shells in the intertidal zones for settlement and landing by land hermit crabs.

CORRESPONDING AUTHOR Katsuyuki Hamasaki hamak@kaiyodai.ac.jp

SUBMITTED 08 August 2019 ACCEPTED 07 November 2019 PUBLISHED 24 January 2020

\section{KeYWORDS}

Coenobita purpureus, Coenobita rugosus, geographical distribution, recruitment, settlement 


\section{INTRODUCTION}

Land hermit crabs of the genus Coenobita Latreille, 1829 are mainly distributed in subtropical and tropical coastal regions (Hartnoll, 1988), and they are scavengers in the coastal ecosystem (Page and Willason, 1983; Thacker, 1996). Land hermit crabs comprise approximately 17 species (Hartnoll, 1988; Poupin, 1996; McLaughlin et al., 2010; Rahayu et al., 2016), and in Japan, five species (C. brevimanus Dana, 1852, C. cavipes Stimpson, 1858, C. purpureus Stimpson, 1858, C. rugosus H. Milne-Edwards, 1837, and C. violascens Heller, 1862) are commonly found on the southern islands of the Ryukyu Archipelago (Nakasone, 1988; 2001; Asakura, 2004; Fujikawa et al., 2017). They have been a Natural Monument Animal since 1970 in Japan, and some species have been listed as "near threatened" on the Red Lists by the Ministry of the Environment of Japan.

Land hermit crabs need the sea for the development of planktonic larvae from zoeae to megalopae (Hamasaki et al., 2015a). After settlement, megalopae acquire empty gastropod shells and migrate onto land; then, they bury themselves in substrata before emerging as first crabs (Harvey, 1992; Brodie, 1999; Hamasaki et al., 2015b). Therefore, the coastal habitats that earlylife-stage crabs use are essential for completing their life cycle.

Hamasaki et al. (2018) conducted surveys on the distributional characteristics of early juvenile land hermit crabs with 1-1.5 mm shield lengths (SL) at several sandy beach and river mouth localities along the coast of Ishigakijima Island in the Ryukyu Archipelago, Japan. The early juveniles of $C$. rugosus were abundant and mainly collected at beach sites, and those of other species were either collected at beach sites ( $C$. purpureus) or river mouth sites (C. violascens) or both the beach and river mouth sites (C. brevimanus and C. cavipes). Thus, the species-specific distributional characteristics of early juvenile land hermit crabs have been investigated on a macro scale along the coast of the island. Sanda et al. (2019) reported the population dynamics including abundance and growth of early juvenile land hermit crabs at four beach sites along the coast of the Boso Peninsula, Japan. However, very little is known about the small-scale distribution patterns of early juvenile land hermit crabs within beach or river mouth localities.
In the present study, as a basis for understanding the important habitats that land hermit crabs use during the sea-to-land transition, we investigated the occurrence and distribution of early juvenile land hermit crabs at a small beach with heterogeneous topography on the Boso Peninsula, Japan.

\section{Materials and Methods}

\section{Field study}

The field study was conducted at a small beach $\left(34^{\circ} 58^{\prime} \mathrm{N}, 139^{\circ} 46^{\prime} \mathrm{E}\right)$ on the Boso Peninsula, Japan (Fig. 1A, B), which is the most northern area where land hermit crabs are found (Sanda et al., 2019). The survey beach occurs in front of the Tateyama Station, Field Science Center, Tokyo University of Marine Science and Technology, Banda, Tateyama, Chiba Prefecture (Fig. 1A, B). In previous surveys that monthly investigated the occurrence of early juvenile land hermit crabs on the beach of Banda, early juveniles of $C$. purpureus and C. rugosus were found starting in August, but they died during the overwintering period (Sanda et al., 2019). Thus, our survey site has an advantage in regard to the detection of only early juvenile land hermit crabs just after landing.

The survey site is a natural sandy beach with rocky areas, and the supratidal zones are generally vegetated with grasses and shrubs intermingled with coastal forests. Six survey points (P1-P6) were established along the beach (Fig. 1C). The topography of the points can be summarized as follows: P1 (Fig. 2A), supratidal zone with a concrete wall and rocky area and intertidal zone with a sandy bottom; P2 (Fig. 2B), supratidal zone with a rocky area and intertidal zone with a bottom of gravel and rock; P3 (Fig. 2C), supratidal zone with sandy and rocky areas, upper and middle intertidal zones with a sandy bottom and lower intertidal zone with a gravel bottom; P4 (Fig. 2D), supratidal zone with a sand bank and intertidal zone with a sandy bottom; P5 (Fig. 2E), supratidal zone with a rocky area and intertidal zone with a bottom of gravel, pebble and rock; P6 (Fig. 2F), supratidal zone with sandy and rocky areas and intertidal zone with a sandy bottom.

In our previous study, the survey areas included P5 and P6 but not the other points considered in the present study, and many early juveniles were found at 

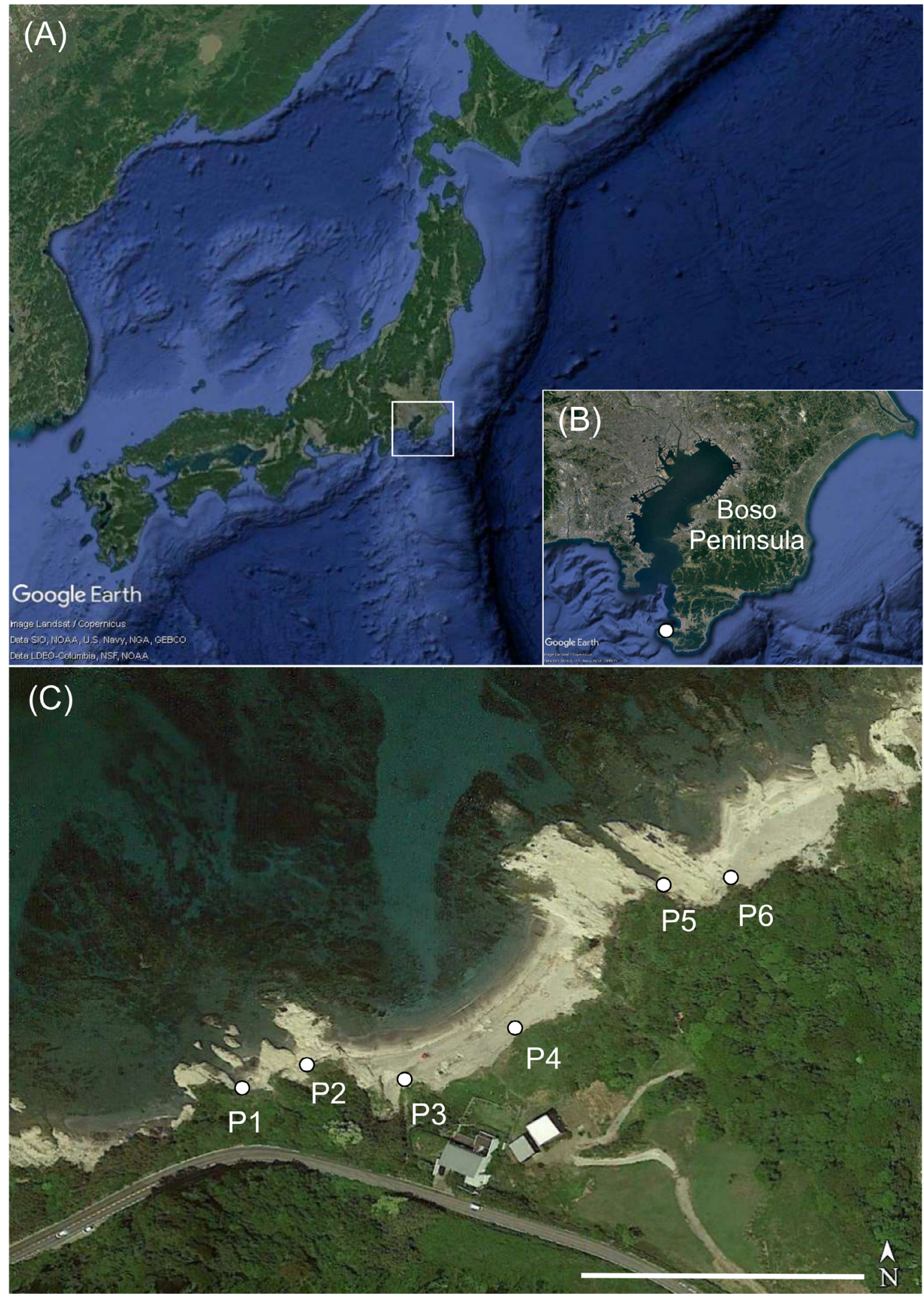

Figure 1. Google Earth photographs showing the Japanese Archipelago (A), Boso Peninsula (B), and survey points at which early juveniles of land hermit crabs were investigated at the small beach of Banda (34 $\left.58^{\prime} \mathrm{N}, 139^{\circ} 46^{\prime} \mathrm{E}\right)$, Chiba Prefecture, Japan (C). The white rectangle in panel (A) indicates the area including the Boso Peninsula. The white circle in panel (B) indicates the survey site at Banda. The six survey points (P1-P6) at the small beach are shown in panel (C). Horizontal white line in panel (C) is a scale bar $(100 \mathrm{~m})$. 

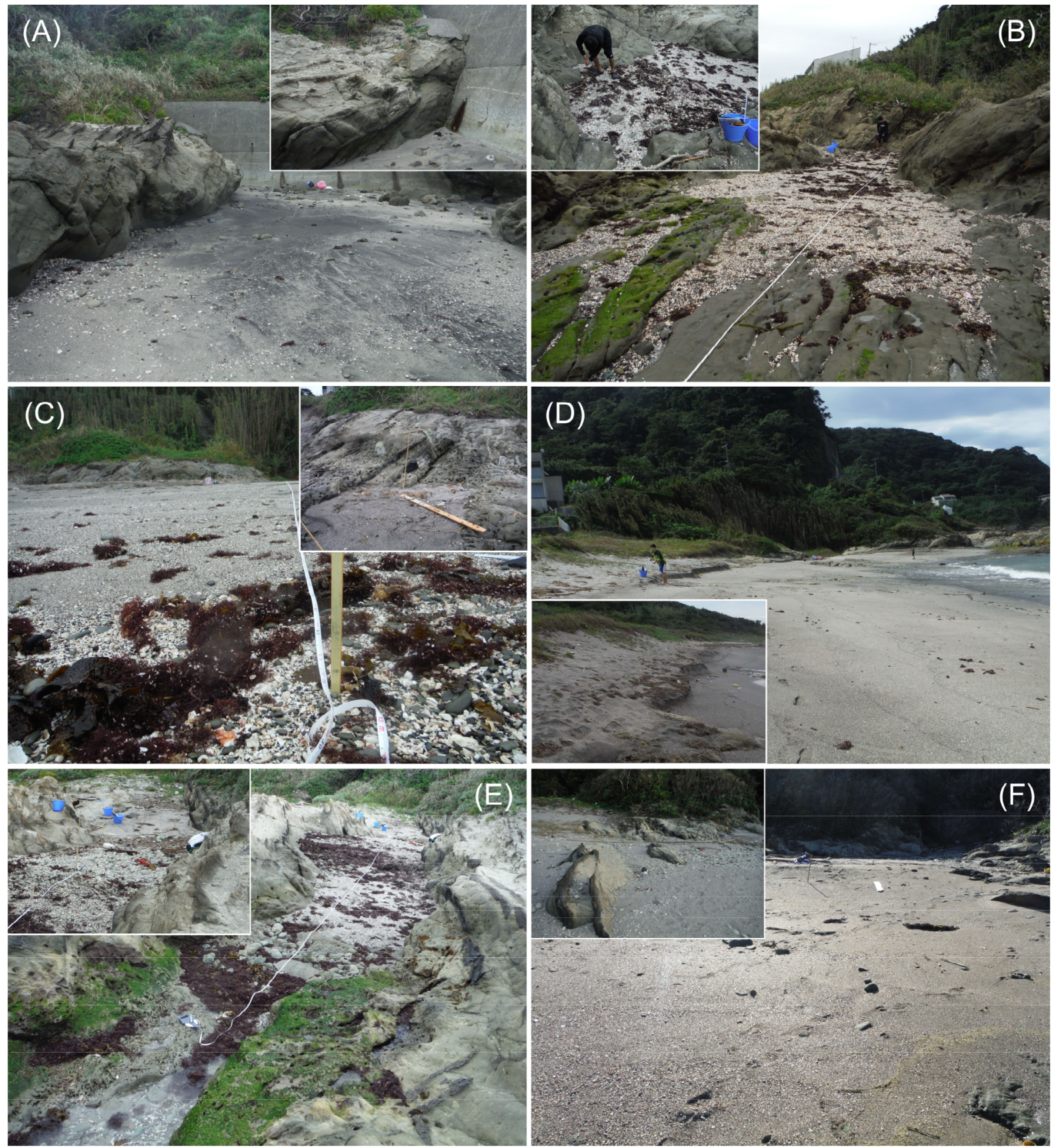

Figure 2. Photographs of the intertidal zones at survey points P1 (A), P2 (B), P3 (C), P4 (D), P5 (E), and P6 (F). The supratidal zone at which the visual search for early juveniles of land hermit crabs was conducted is superimposed on each survey point panel.

P5 starting at the beginning of the survey in late August in each year from 2012 to 2014 (Sanda et al., 2019). In the present study, to elucidate the spatial stability of the habitats that early juvenile land hermit crabs use, we conducted field surveys every 1-3 days from the middle of July to late August in 2015 and 2016. Additionally, field surveys were carried out once in late September and late October before the beginning of the overwintering period (Sanda et al., 2019) in both years. An investigator visually searched for and counted the crabs in the supratidal zone $\left(\sim 15 \mathrm{~m}^{2}\right)$ at each survey point for $\sim 20 \mathrm{~min}$ in the afternoon. Some crabs were collected at P2 and P5, with a high abundance of early juveniles (see the Results section) and then transferred to the laboratory of Tateyama Station. We then measured the dactylus length (DL) of the captured crabs, and the DL was converted to the SL according to Sanda et al. (2019). In the 2015 survey, 
length of the gastropod shells occupied by the crabs was also measured. We did not identify the species of gastropod shells. After the measurements, the crabs were returned to the points from which they were collected. The species of land hermit crabs with $>1.5$ $\mathrm{mm}$ SL could be identified with the aid of the speciesspecific body color patterns (Hamasaki et al., 2017). In the present study, the majority of early juvenile land hermit crabs were smaller than $1.5 \mathrm{~mm}$ SL; therefore, we did not identify the species of land hermit crabs. However, newly landed juveniles have been genetically identified as either C. purpureus or C. rugosus, and $C$. purpureus is the dominant species landing on the coast of the Boso Peninsula (Sanda et al., 2019).

Empty gastropod shells are indispensable for the life of hermit crabs (Hazlett, 1981). Therefore, to infer the abundance of empty gastropod shells around the survey points, we conducted line-transect sampling once in the intertidal zones at each point on 29 or 30 September 2016. We assumed that empty gastropod shells in the intertidal zones could be a supply source for shells used by early juveniles as well as megalopae of the land hermit crabs. A transect was established during the lowest ebb of the tide, and four quadrats $(50 \times 50 \mathrm{~cm})$ were placed at equal intervals from the high-water to low-water lines. The bottom sediment to $1 \mathrm{~cm}$ depth was removed from each quadrat and taken to the laboratory. Early juveniles of land hermit crabs collected in 2015 occupied gastropod shells with approximately 3-13 $\mathrm{mm}$ in length (Fig. 3); therefore, we sorted and counted the empty gastropod shells 3-13 $\mathrm{mm}$ in length from the sediment samples.

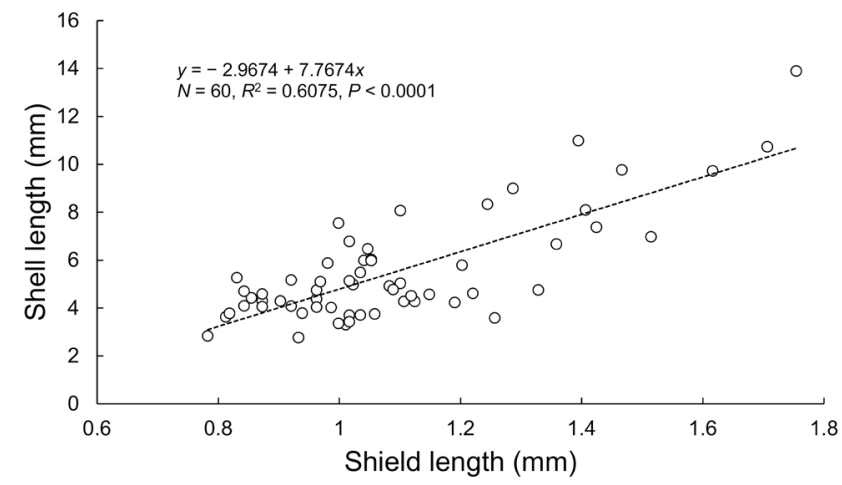

Figure 3. Relationship between shield length of early juvenile land hermit crabs and length of gastropod shells occupied by the crabs in the 2015 survey.

\section{Statistical analysis}

Statistical analyses were performed using $\mathrm{R}$ statistical software (R 3.5.2; R Core Team, 2018) at the $5 \%$ significance level. We employed a linear model (LM) to compare the abundance of early juveniles among survey points (P1-P6) and between years (2015 and 2016). In this analysis, the number of juveniles $(n)$ was logarithmically transformed according to $\log _{e}(n+0.5)$ (Yamamura, 1999) because the count data included zeros. The abundance of early juveniles was represented by the mean value or maximum value of the number of juveniles counted at each point during the survey period in each year. The abundance of early juveniles was compared between sediment types in the intertidal zone [sand (P1, P3, P4 and P6) and gravel (P2 and P5)] and the different years of the study (2015 and 2016). The number of empty gastropod shells $(n)$ was compared among survey points and between sediment types after being logarithmically transformed according to $\log _{\mathrm{e}}(n+0.5)$. The statistical significance of the categorical explanatory variables (survey points, years and sediment types) in the LM analyses was evaluated with an F-test using the Anova function (Type II) implemented in the car package (Fox and Weisberg, 2011).

To assess the spatial stability of the occurrence of early juveniles on the beach, the Pearson's productmoment correlation coefficient between the mean number or maximum number of juveniles counted at each point during the 2015 and 2016 surveys was calculated and tested with a $t$-test. The relationship between the mean number of empty gastropod shells and abundance of early juveniles at the different survey points in 2016 was evaluated with Pearson's correlation coefficient.

To examine the temporal variation in the growth of early juveniles, the SL values of the crabs collected in late October were compared between the 2015 and 2016 surveys with Welch's $t$-test.

\section{Results}

In the 2015 survey, one early juvenile with a 1.0 mm SL was found at P5 on 4 August (Fig. 4A); then, the number of early juveniles increased through 
August to late September. In the 2016 survey, early juveniles appeared later than in 2015, and 63, 1 and 15 individuals were found at P2, P3 and P5 on 21 August, respectively (Fig. 4B). Then, the number of early juveniles increased from late September to late October. No juveniles were found at $\mathrm{P} 4$ in either year. Megalopae were not found during the surveys. The abundance of early juveniles varied among survey points (mean number: $F=49.12, d f=5, P=0.0003$; maximum number, $F=68.39, d f=5, P=0.0001)$ and years (mean number: $F=6.038, d f=1, P=0.0574$; maximum number: $F=12.34, d f=1, P=0.0171$ ). Early juveniles were more abundant at survey points with gravel sediment (mean number: $F=9.843, d f=$ $1, P=0.0120$; maximum number: $F=4.345, d f=1$, $P=0.0668$ ) regardless of survey year (mean value: $\mathrm{F}=0.4540, d f=1, P=0.5174$; maximum number: $\mathrm{F}=0.4746, d f=1, P=0.5083)$. Overall, the abundance of early juveniles tended to be large at P2 and P5, which have gravel sediment throughout the intertidal zone, in both years, and it was larger in 2015 than in 2016 (Fig. 4). The Pearson's correlation coefficient between number of early juveniles counted at each point in the 2015 and 2016 surveys was high (mean number: $r=0.9786, t=9.505, d f=4, P=0.0007$; maximum number, $r=0.9059, t=4.279, d f=4, P=0.0129)$. The SL of early juveniles was around $1 \mathrm{~mm}$ (Table 1 ), and the body size in late October was larger in 2015 than in $2016(t=3.753, d f=22.01, P=0.0011)$.
The amount of empty gastropod shells varied among the intertidal zones of the survey points $(\mathrm{F}=11.86, d f$ $=5, P<0.0001)$, and it was large at P2 and P5, which have gravel sediment $(F=17.12, d f=1, P=0.0004)$ (Fig. 5). The amount of shells affected the abundance of early juveniles, as a significant and high Pearson's

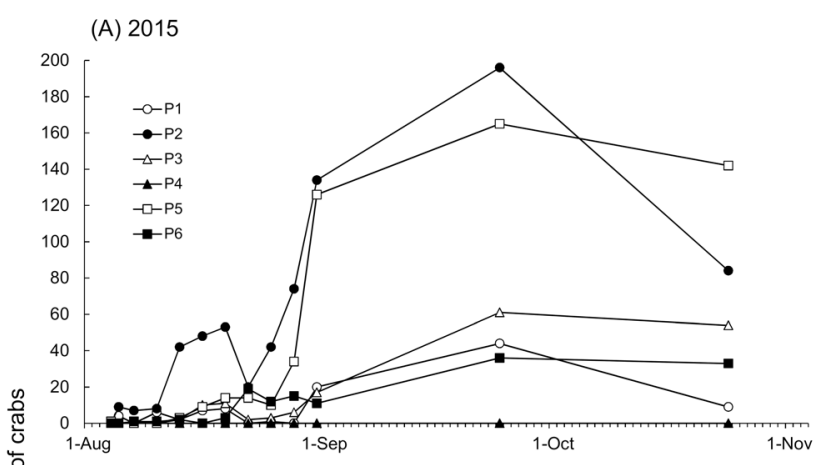

(B) 2016

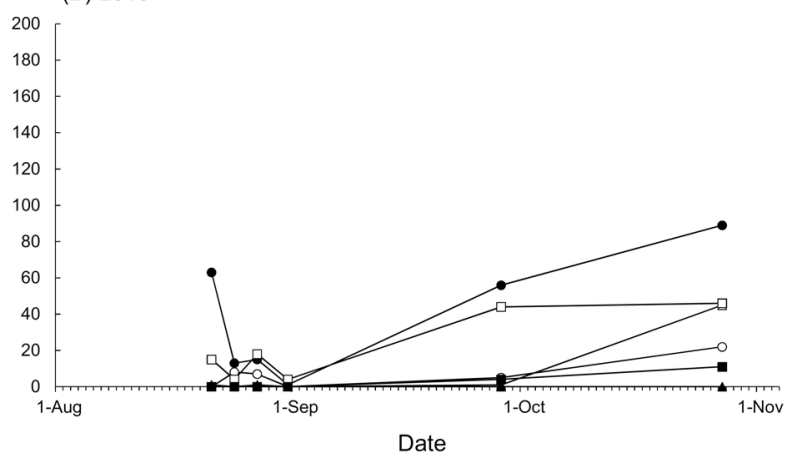

Figure 4. Number of early juveniles counted at each survey point in the 2015 (A) and 2016 (B) surveys.

Table 1. Shield length of early juvenile land hermit crabs at the beach of Banda on the Boso Peninsula, Japan.

\begin{tabular}{|c|c|c|c|c|c|c|}
\hline \multirow{2}{*}{ Year } & \multirow{2}{*}{ Date } & \multicolumn{5}{|c|}{ Shield length (mm) } \\
\hline & & $n$ & Mean & SD & Min. & Max. \\
\hline \multirow[t]{8}{*}{2015} & 4-Aug & 1 & 1.02 & & & \\
\hline & 10-Aug & 8 & 0.96 & 0.08 & 0.84 & 1.10 \\
\hline & 13-Aug & 8 & 0.86 & 0.05 & 0.78 & 0.96 \\
\hline & 22-Aug & 8 & 0.98 & 0.06 & 0.82 & 1.06 \\
\hline & 25-Aug & 10 & 1.03 & 0.06 & 0.92 & 1.12 \\
\hline & 31-Aug & 30 & 1.00 & 0.18 & 0.82 & 1.35 \\
\hline & 24-Sep & 10 & 1.16 & 0.17 & 0.97 & 1.47 \\
\hline & 24-Oct & 15 & 1.35 & 0.21 & 1.09 & 1.75 \\
\hline \multirow[t]{6}{*}{2016} & 21-Aug & 20 & 0.90 & 0.05 & 0.84 & 0.99 \\
\hline & 24-Aug & 15 & 0.94 & 0.07 & 0.85 & 1.11 \\
\hline & 27-Aug & 23 & 0.92 & 0.06 & 0.81 & 1.05 \\
\hline & 31-Aug & 7 & 0.95 & 0.07 & 0.87 & 1.12 \\
\hline & 24-Sep & 23 & 0.92 & 0.08 & 0.78 & 1.09 \\
\hline & $27-$ Oct & 15 & 1.12 & 0.12 & 0.91 & 1.30 \\
\hline
\end{tabular}


correlation coefficient between these variables was observed (mean number: $r=0.9380, t=5.410, d f=4$, $P=0.0057$; maximum number: $r=0.8690, t=3.513$, $d f=4, P=0.0246)$.

\section{Discussion}

\section{Recruitment of land hermit crabs}

Our previous surveys revealed that juvenile land hermit crabs grew to around 2.4-2.6 $\mathrm{mm}$ SL one year after landing on the Boso Peninsula (Sanda et al., 2019). In the present study, the maximum body size of juveniles found at the beach of Banda was $\sim 1.8$ $\mathrm{mm}$ SL. Thus, we could investigate the occurrence and distribution of early juvenile land hermit crabs and determine the timing of the first appearance of juveniles at the beach of Banda; it was earlier in 2015 (early August) than in 2016 (late August). The body size of juveniles in late October before the beginning of the overwintering period was smaller in 2016 than in 2015, reflecting the recruitment delay in 2016. Additionally, abundance of early juveniles varied between survey years, and it was larger in 2015 than in 2016. Temporal variation in the occurrence of early juveniles on the Boso Peninsula was also detected in our previous study (Sanda et al., 2019).

Land hermit crab populations mainly occur on the southern islands of the Ryukyu Archipelago, Japan (< $30^{\circ} \mathrm{N}$ ), and the reproductive season of land hermit crabs occurs in summer (Nakasone, 2001; Fujikawa et al., 2017). Sanda et al. (2019) inferred that land hermit crab larvae migrate to the Boso Peninsula in summer via the Kuroshio Current which flows from near Taiwan through the Ryukyu Archipelago to the Pacific coast of Japan in the north-western Pacific region. The Kuroshio Current pathway, which fluctuates temporarily and seasonally (Nakata et al., 2000; Douglass et al., 2012), might affect the recruitment of land hermit crabs to the coast of the Boso Peninsula, and Sanda et al. (2019) suggest that the abundance of early juveniles found at Banda was small when the Kuroshio Current tended to flow in a relatively offshore direction. Here, the distance from the Boso Peninsula [Cape Nojimazaki ( $34^{\circ} 54^{\prime} \mathrm{N}$, $\left.\left.139^{\circ} 53^{\prime} \mathrm{E}\right)\right]$ to the centre of the Kuroshio Current is shown during the period from July to October in
2015 and 2016 in Fig. 6, based on a database from the Hydrographic and Oceanographic Department, Japan Coast Guard. The overall pathway of the Kuroshio Current changed from nearshore to offshore directions from July to October 2015, and the opposite trend observed in the 2016 pathway might be responsible for the 0.5-1 month delay and fewer abundance in recruitment of land hermit crabs at the beach of Banda in 2016. Although there is no information on how the directions of the Kuroshio Current off Cape Nojimazaki affect the local tidal current system near the beach of Banda, the present study further suggests that successful colonization by land hermit crabs in the northernmost distributional area might be influenced by variation in the Kuroshio Current pathway.

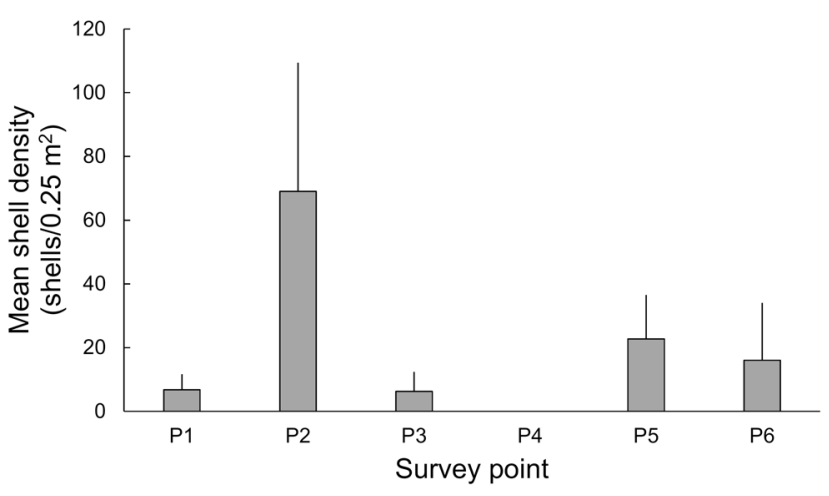

Figure 5. Mean number of empty gastropod shells in four quadrats $(50 \times 50 \mathrm{~cm}$ each) established along the intertidal zones at the survey points (P1-P6). Vertical bars indicate the standard deviations.

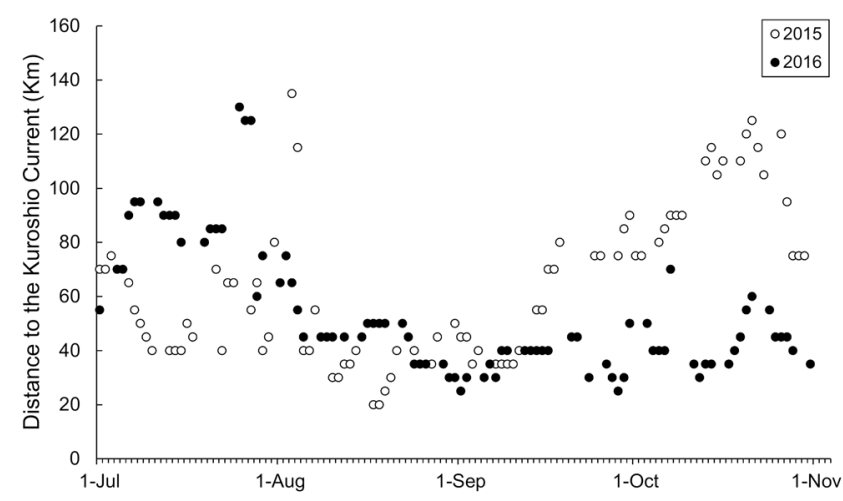

Figure 6. Distance from the Boso Peninsula [Cape Nojimazaki $\left.\left(34^{\circ} 54^{\prime} \mathrm{N}, 139^{\circ} 53^{\prime} \mathrm{E}\right)\right]$ to the centre of the Kuroshio Current from July to October 2015 and 2016 based on a database from the Hydrographic and Oceanographic Department, Japan Coast Guard (https://www1.kaiho.mlit.go.jp/KANKYO/KAIYO/ qboc/kurosio-num.html). 
Important habitats for land hermit crabs during the seato-land transition

The coconut crab [Birgus latro (Linnaeus, 1767)], a sister taxon of the genus Coenobita, exhibits a similar early life history to the land hermit crabs (Hartnoll, 1988; Greenaway, 2003). Hamasaki et al. (2015c) examined the substrate preferences (open sand, coral fragments, or brown algae) of coconut crab megalopae during settlement and reported that they selected structurally complex substrata (coral fragments or brown algae). Imafuku (2002) found newly landed megalopae of land hermit crabs in clusters of algae stranded around the high-water line at the beach of Kikaijima Island, Japan, where C. purpureus was the most abundant species. It has been demonstrated that megalopae and early juveniles of brachyuran and anomuran crabs prefer structurally complex habitats that provide refuge against predation (Fernandez et al., 1993; Dittel et al., 1996; Stevens and Swiney, 2005; Stoner, 2009). Field studies have demonstrated that the quality and quantity of empty gastropod shells strongly affect the settlement rate of marine hermit crabs (Asakura, 1991; Worcester and Gaines, 1997; Oba and Goshima, 2004). Our field surveys revealed the heterogeneous distributions of early juvenile land hermit crabs on the beach of Banda and that the distributional characteristics of juveniles were spatially stable. Early juveniles were abundant at P2 and P5, where the gravel/pebble bottom extended throughout the intertidal zones and there was a large amount of empty gastropod shells. Additionally, stranded clusters of algae were observed from the high to low water lines in the intertidal zones at P2 and P5 (Fig. 2). Thus, the intertidal zones at P2 and P5 appear to have suitable abiotic/biotic features for settlement and landing by land hermit crabs during the sea-to-land transitions.

The present study demonstrated the heterogeneous distribution of early juveniles of land hermit crabs on a small beach and suggested the importance of the sediment types and amount of empty gastropod shells in the intertidal zones for settlement and landing by land hermit crabs. We examined the amount of empty gastropod shells ( 3-13 mm in length) that were occupied by early juveniles with $\sim 0.8-1.8 \mathrm{~mm}$ SL. To further elucidate the important habitats for successful settlement and landing by new recruits of land hermit crabs, future field and laboratory studies are required to investigate the abundance and size frequency distribution of empty shells for respective gastropod species or shell forms preferred by megalopae and early juveniles.

\section{ACKNOWLedgements}

We would like to acknowledge the Chiba Prefectural Board of Education and the Agency for Cultural Affairs, government of Japan (License Certificate No. 4-1), for permission to collect the land hermit crabs. We thank the members of the laboratory for helping with the field work. Comments and suggestions from two anonymous reviewers were much appreciated. This study was supported by Grants in-Aid for Scientific Research B24310171 to KH from the Ministry of Education, Culture, Sports, Science, and Technology of Japan.

\section{References}

Asakura, A. 1991. Population ecology of the sand-dwelling hermit crab Diogenes nitidimanus. IV. Larval settlement. Marine Ecology Progress Series, 78: 139-146.

Asakura, A. 2004. Recent topics on taxonomy of hermit crabs from Japanese waters - Family Coenobitidae. Aquabiology, 26: 83-89. (in Japanese with English abstract)

Brodie, R.J. 1999. Ontogeny of shell-related behaviors and transition to land in the terrestrial hermit crab Coenobita compressus H. Milne Edwards. Journal of Experimental Marine Biology and Ecology, 241:67-80.

Dittel, A.; Epifanio, C.E. and Natunewicz, C. 1996. Predation o mud crab megalopae, Panopeus herbstii H.Mile Edwards: effect of habitat complexity, predator species and postlarval densities. Journal of Experimental Marine Biology and Ecology, 198: 191-202.

Douglass, E.M.; Jayne, S.R.; Bryan, F.O.; Peacock, S. and Maltrud, M. 2012. Kuroshio pathways in a climatologically forced model. Journal of Oceanography, 68: 625-639.

Fernandez, M.; Iribarne, O. and Armstrong, D. 1993. Habitat selection by young-of-the-year Dungeness crab Cancer magister and predation risk in intertidal habitats. Marine Ecology Progress Series, 92: 171-177.

Fox, J. and Weisberg, S. 2011. An R companion to applied regression. $2^{\text {nd }}$ ed. Thousand Oaks, Sage Publications, 472p.

Fujikawa, S.; Hamasaki, K.; Sanda, T.; Ishiyama, N.; Tsuru, T.; Dan. S. and Kitada, S. 2017. Distributional characteristics of terrestrial hermit crabs along the coasts of Ishigakijima Island and Iriomotejima Island, Ryukyu Archipelago, Japan. Bulletin of the Biogeographical Society of Japan, 71:25-38. (in Japanese with English abstract)

Greenaway, P. 2003. Terrestrial adaptations in the Anomura (Crustacea: Decapoda). Memoirs of Museum Victoria, 60: 13-26. 
Hamasaki, K.; Kato, S.; Murakami, Y.; Dan, S. and Kitada, S. 2015a. Larval growth, development and duration in terrestrial hermit crabs. Sexuality and Early Development in Aquatic Organisms, 1: 93-107.

Hamasaki, K.; Hatta, S.; Ishikawa, T.; Yamashita, S.; Dan, S. and Kitada, S. 2015b. Emigration behaviour and moulting during the sea-to-land transition of terrestrial hermit crabs under laboratory conditions. Invertebrate Biology, 134: 318-331.

Hamasaki, K.; Ishiyama, N. and Kitada, S. 2015c. Settlement behavior and substrate preference of the coconut crab Birgus latro megalopae on natural substrata in the laboratory. Journal of Experimental Marine Biology and Ecology, 468: 21-28.

Hamasaki, K.; Tsuru, T.; Sanda, T.; Fujikawa, S.; Dan, S. and Kitada, S. 2017. Ontogenetic change of body color patterns in laboratory-raised juveniles of six terrestrial hermit crab species. Zootaxa 4226, 521-545.

Hamasaki, K.; Fujikawa, S.; Iizuka, C.; Sanda, T.; Tsuru, T.; Imai, H. and Kitada, S. 2018. Recruitment to adult habitats in terrestrial hermit crabs on the coast of Ishigakijima Island, Ryukyu Archipelago, Japan. Invertebrate Biology, 137: 3-16.

Hartnoll, R.G. 1988. Evolution, systematic, and geographical distribution. p. 6-54. In: W.W. Burggren and B.R. McMahon (eds), Biology of the land crabs. New York, Cambridge University Press.

Harvey, A.W. 1992. Abbreviated larval development in the Australian terrestrial hermit crab Coenobita variabilis McCulloch (Anomura: Coenobitidae). Journal of Crustacean Biology, 12: 196-209.

Hazlett, B.A. 1981. The behavioral ecology of hermit crab. Annual Review of Ecology, Evolution, and Systematics, 12: 1-22.

Imafuku, M. 2002. Ecology of the land hermit crab Coenobita purpureus on Kikaijima Island. II. Breeding behaviour, food, predator, orientation and the environment. Memoirs of the Faculty of Science, Kyoto University (Series Biology), 18: 15-34.

McLaughlin, P.A.; Komai, T.; Lemaitre, R. and Rahayu, D.L. 2010. Annotated checklist of Anomura decapod crustaceans of the world (exclusive of the Kiwaoidea and families Chirostylidae and Galatheidae of the Galatheoidea) Part I — Lithodoidea, Lomisoidea and Paguroidea. The Raffles Bulletin of Zoology, Supplement 23: 5-107.

Nakasone, Y. 1988. Land hermit crabs from the Ryukyus, Japan, with a description of a new species from the Philippines (Crustacea, Decapoda, Coenobitidae). Zoological Science, 5: $165-178$.

Nakasone, Y. 2001. Reproductive biology of three land hermit crabs (Decapoda: Anomura: Coenobitidae) in Okinawa, Japan. Pacific Science, 55: 157-169.
Nakata, H.; Funakoshi, S. and Nakamura, M. 2000. Alternating dominance of postlarval sardine and anchovy caught by coastal fishery in relation to the Kuroshio meander in the Enshu-nada Sea. Fisheries Oceanography, 9: 248-258.

Oba, T. and Goshima, S. 2004. Temporal and spatial settlement patterns of sympatric hermit crabs and the influence of shell resource availability. Marine Biology, 144: 871-879.

Page, H.M. and Willason, S.W. 1983. Feeding activity patterns and carrion removal by terrestrial hermit crabs at Enewetak Atoll, Marshall Islands. Pacific Science, 37: 151- 155.

Poupin, J. 1996. Crustacea Decapoda of French Polynesia (Astacidea, Palinuridea, Anomura, Brachyura). Atoll Research Bulletin, 442: 1-114.

R Core Team. 2018. R: A language and environment for statistical computing. R Foundation for Statistical Computing, Vienna. Available at https://www.R-project.org/. Accessed on 20 March 2019.

Rahayu, D.L.; Shih, H.-T. and Ng, P.K.L. 2016. A new species of land hermit crab in the genus Coenobita Latreille, 1829 from Singapore, Malaysia and Indonesia, previously confused with C. cavipes Stimpson, 1858 (Crustacea: Decapoda: Anomura: Coenobitidae). The Raffles Bulletin of Zoology, Supplement 34: 470-488.

Sanda, T.; Hamasaki, K.; Dan, S. and Kitada, S. 2019. Expansion of the northern geographical distribution of land hermit crab populations: colonization and overwintering success of Coenobita purpureus on the coast of Boso Peninsula, Japan. Zoological Studies, 58: 25.

Stevens, B.G. and Swiney, K.M. 2005. Post-settlement effects of habitat type and predator size on cannibalism of glaucothoe and juveniles of red king crab Paralithodes camtschaticus. Journal of Experimental Marine Biology and Ecology, 321: $1-11$.

Stoner, A.W. 2009. Habitat-mediated survival of newly settled red king crab in the presence of a predatory fish: role of habitat complexity and heterogeneity. Journal of Experimental Marine Biology and Ecology, 382: 54-60.

Thacker, R.W. 1996. Food choices of land hermit crabs (Coenobita compressus $\mathrm{H}$. Milne Edwards) depend on past experience. Journal of Experimental Marine Biology and Ecology, 199: 179-191.

Worcester, S.E. and Gaines, S.D. 1997. Quantifying hermit crab recruitment rates and megalopal shell selection on waveswept shores. Marine Ecology Progress Series, 157: 307-310.

Yamamura, K. 1999. Transformation using $(x+0.5)$ to stabilize the variance of populations. Researches on Population Ecology, 41: 229-234. 